Technical Paper

\title{
Aplikasi Ozon Untuk Mempertahankan Kualitas Buah Duku
}

\author{
Ozone Application For Maintain Quality of Duku \\ Andi Ani Kuswati, Program Studi Teknologi Pascapanen, Institut Pertanian Bogor. \\ Email: kacaberdebu.andianikuswati@gmail.com \\ Emmy Darmawati, Departemen Teknik Mesin dan Biosistem, Institut Pertanian Bogor. \\ Email: darmawatihandono@gmail.com \\ Siti Mariana Widayanti, Balai Besar Pascapanen. Email: sm.widayanti@gmail.com
}

\begin{abstract}
Poor maintenance of duku plants makes the harvested duku potentially bring microbial contaminants so that it can accelerate damage. Ozone technology has been widely used to inhibit the development of microorganisms in fresh horticultural storage. The purpose of this study was to examine the effect of duration of ozone exposure at a rate of $1.38 \times 10-4 \mathrm{ppm} /$ second on changes in quality of storage. The duration of ozone exposure studied was 20, 40 and 60 seconds as treatment. Microbial growth was measured using a TPC test, while the quality parameters evaluated were color change, hardness, total soluble solids and weight loss. The ozone treatment which best effect is exposure ozone 60 seconds. The treatment was able to withstand microbial growth up to 6.11 (log cfu/g) compared to control on the sixth day of storage with better duku quality based on brix value and weight loss with values of $17.8^{\circ}$ brix and $0.87 \%$, respectively. But the color and hardness parameters of the fruit, ozone treatment of 40 seconds produces a better value. Ozone treatment with exposure for 40-60 seconds can be applied to maintain the quality of the duku $14 \pm 1^{\circ} \mathrm{C}$.
\end{abstract}

Keywords: ozone, duku, TPC, exposure duration

\begin{abstract}
Abstrak
Perawatan tanaman duku yang masih kurang baik, membuat buah duku yang dipanen berpotensi membawa kontaminan mikroorganisme dari lahan sehingga turut mempercepat kerusakan buah. Teknologi ozon telah banyak digunakan untuk menghambat perkembangan mikroorganisme pada penyimpanan hortikultura segar. Tujuan penelitian adalah mengkaji pengaruh durasi pemaparan ozon dengan laju $1.38 \times 10^{-4} \mathrm{ppm} /$ detik terhadap perubahan mutu duku dalam penyimpanan. Durasi pemaparan ozon yang dikaji adalah 20, 40, dan 60 detik sebagai perlakuan. Penelitian dilakukan menggunakan Rancangan Acak Lengkap (RAL). Pertumbuhan mikroba diukur menggunakan uji TPC, sedangkan parameter mutu yang dikaji adalah perubahan warna, kekerasan, total padatan terlarut (TPT) dan susut bobot. Data dianalisa

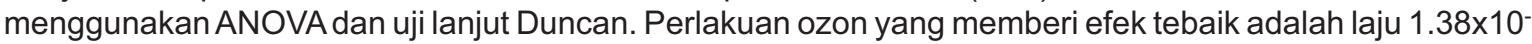
${ }^{4} \mathrm{ppm} /$ detik dengan paparan 60 detik. Perlakuan tersebut mampu menahan pertumbuhan mikroba hingga 6.11 (log cfu/g) dibanding kontrol pada hari ke enam penyimpanan dengan mutu duku yang lebih baik berdasarkan nilai TPT dan susut bobot dengan nilai masing-masing adalah $17.8^{\circ}$ briks dan $0.87 \%$. Namun untuk parameter warna dan kekerasan buah, perlakuan ozon 40 detik menghasilkan nilai yang lebih baik. Pelakuan ozon dengan paparan selama 40-60 detik dapat diaplikasikan untuk mempertahankan mutu duku yang dikombinasikan dengan penyimpanan suhu $14 \pm 1^{\circ} \mathrm{C}$.
\end{abstract}

Kata Kunci: ozon, buah duku, total plate count, durasi paparan

Diterima: 21 Januari 2020; Disetujui: 1 April 2020 


\section{Pendahuluan}

Buah duku merupakan buah tropis, rasa manis yang khas, serta kandungan nutrisi yang cukup membuat permintaan pasar akan duku terus meningkat. Namun buah duku tergolong buah yang mudah rusak dan tidak dapat disimpan dalam waktu yang lama. Perubahan warna setelah 2-3 hari setelah dipanen seperti pencoklatan kulit mempengaruhi umur simpan dan harga di pasar menjadi menurun (Tilaar et al. 2007). Budidaya yang belum baik, membuat buah duku yang dipanen berpotensi membawa kontaminan mikroorganisme dari lahan, sehingga turut mempercepat kerusakan buah. Penggunaan klorin sebagai agen sanitasi telah banyak digunakan pada produk segar, namun adanya batasan dalam penggunaannya membuat efeknya terbatas dalam membunuh bakteri pada permukaan buah dan sayuran. Hasil penelitian yang dilakukan oleh $\mathrm{Xu}$ (1999) menunjukkan penggunaan klorin dalam batas sesuai peraturan hanya mampu menurunkan populasi mikroba 1 hingga 2 log. Selain itu penggunaan bahan ini dikhawatirkan meninggalkan residu dalam buah yang membahayakan kesehatan. Salah satu usaha penanganan pascapanen yang ramah lingkungan dan mulai banyak diteliti adalah teknologi ozon. Ozon bersifat auto decompose karena oksigen yang dihasilkan tidak meninggalkan residu ke dalam buah dan sayuran, selain itu ozon juga mudah terurai menjadi oksigen normal ketika terkena sinar matahari (O'Donnell et al. 2012; Asgar 2014). Mekanisme ozon menghancurkan mikroorganisme dengan bereaksi dengan komponen seluler teroksidasi, terutama yang mengandung ikatan rangkap, gugus sulfhidril, dan cincin fenolik, reaksi ini mengakibatkan kerusakan sel dan kematian mikroorganisme (Aafia et al. 2018). Sirichote et al. (2015) juga melaporkan bahwa Buah Longkong yang diberi ozon pada 1 ppm mampu mengurangi kerusakan dan menghambat pertumbuhan mikroba, bertahan selama 12 hari penyimpanan. Thaer et al. (2015) juga melaporkan buah apel yang dipapari ozon 0.5 ppm efektif mengurangi pertumbuhan mikroba $P$.expansum dan bertahan selama 2 bulan. Hal inilah yang melatar belakangi perlunya dilakukan kajian lanjut tentang pengaplikasian ozon untuk mempertahankan kualitas buah-buahan dan menjadi alternatif penanganan pascapanen buah duku. Penelitian tentang penanganan pascapanen buah duku masih sedikit dilakukan, sehingga diperlukan kajian-kajian penanganan yang tepat untuk mempertahankan kualitas dan memperpanjang umur simpan buah duku.

\section{Bahan dan Metode}

\section{Bahan dan Alat}

Bahan yang digunakan adalah buah duku yang berasal dari Petani Kabupaten Bogor, dan plastik
PP ketebalan 0,05 mm sebagai kemasan dalam penyimpanan. Peralatan yang digunakan terdiri atas count counter, F900 ethylene analyzer portable, ozoniser, chromameter Minolta CR-300, Sun rheo meter CR-300, dan hand-held refractometer ATAGO Master Serial (ATC), impulse sealer.

\section{Lokasi Penelitian}

Penelitian dilaksanakan di Laboratorium Teknik Pengolahan Pangan dan Hasil Pertanian Insitut Pertanian Bogor, Laboratorium Fisika dan Laboratorium Kimia Balai Besar Penelitian dan Pengembangan Pascapanen Pertanian, Bogor pada bulan November 2018- April 2019.

\section{Prosedur Penelitian}

Penelitian terdiri atas empat tahapan yaitu: 1) persiapan sampel penelitian, 2) Pengukuran respirasi buah duku 3) pengaplikasian gas ozon (ozonisasi) dan penyimpanan 4) analisis perubahan fisiologi buah duku.

\section{Persiapan Sampel Penelitian}

Tahapan persiapan sampel adalah mensortasi berdasarkan visual buah (permukaan kulit buah bersih, bebas penyakit dan tidak rusak), ukuran buah (standar pasar grade A dengan diameter 2.7$3.3 \mathrm{~cm}$ ). Jumlah sampel yang dibutuhkan sebanyak 171 sampel dengan berat per sampel 250 gram untuk tiga perlakuan, tiga ulangan dan pengamatan selama penyimpanan 9 hari dengan pengambilan data setiap 3 hari.

\section{Pengukuran Respirasi Buah Duku}

Pengukuran respirasi sebagai indikator laju metabolism komoditas bahan segar yang mempengaruhi perubahan mutu buah setelah dipanen. Besarnya respirasi dapat diukur dengan penentuan jumlah substrat yang dikeluarkan dan yang diserap (Sujatha dan Ni 2017). Respirasi diukur menggunakan alat F900 ethylene analyzer portable yang dilengkapi sensor pengukur $\mathrm{CO}_{2}$ dan $\mathrm{O}_{2}$ dengan laju kecepatan udara pengambilan sampel $80 \mathrm{ml} /$ menit. Pengukuran respirasi buah dilakukan dengan memasukkan 500 gram duku ke dalam camber, memasang 2 selang input dan output penghubung camber dengan alat, memberikan nama file yang akan menyimpan data hasil pengukuran. Pengukuran dimulai dengan menekan tombol panah kanan pada alat, pembacaan data terukur setiap 5 detik. Data produksi $\mathrm{CO}_{2}$ dan konsumsi $\mathrm{O}_{2}$ akan tampil di layar LCD. Saat pengukuran data akan terekam otomatis dan tersimpan dalam kartu memori. Pengukuran respirasi buah duku pada hari pertama dilakukan setiap 3 jam sekali, hari kedua 12 jam sekali dan hari ketiga setiap 24 jam sekali. Pengukuran respirasi dihentikan memasuki fase pembusukan. 


\section{Pengaplikasian Gas Ozon (Ozonisasi) pada Penyimpanan Buah Duku}

Alat ozoniser yang digunakan mempunyai kemampuan output maksimal $1.38 \times 10^{-4} \mathrm{ppm} /$ detik. Buah duku yang telah disortir dimasukkan kedalam camber yang dilengkapi selang penghubung aliran gas ozon dengan alat ozoniser. Pengoperasian alat menyesuaikan perlakuan dengan durasi waktu paparan ozon masing-masing yaitu: 0, 20, 40, dan 60 detik (Yanuriati et al. 2007). Setelah pemaparan ozon, buah dikemas menggunakan plastik Polyprophilene (PP) yang dilengkapi perforasi berdiameter $0.5 \mathrm{~cm}$ dengan 5 lubang dan disimpan pada suhu $14 \pm 1^{\circ} \mathrm{C}$ (DTI 2008). Plastik jenis PP dipilih karena memiliki kemampuan melewatkan uap yang rendah sehingga baik digunakan untuk pengemasan sayuran dan buahbuahan. Pemberian perforasi untuk mencegah terjadinya pengembunan dalam kemasan yang dapat mempercepat kerusakan buah.

\section{Pengukuran Pertumbuhan Mikroba}

Pertumbuhan mikroba berdasarkan nilai TPC dengan pengenceran $10^{-4}-10^{-6}$ yang dilakukan pada media PCA, dan diinkubasi selama 48 jam pada suhu $37^{\circ} \mathrm{C}$, kemudian pengamatan pertumbuhan koloni serta perhitungan jumlah mikroorganisme.

TPC $(c f u / g)=$ jumlah Koloni per cawan $\frac{1}{\text { pengencer }}$

\section{Pengukuran Perubahan Fisiologi Buah Duku}

Perubahan mutu selama penyimpanan diamati selama: 0, 3, 6, dan 9 hari penyimpanan. Penurunan kualitas seperti pembusukan buah ditandai dengan perubahan warna, perubahan kekerasan, total padatan terlarut, dan kenaikan susut bobot. Pengukuran warna dilakukan menggunakan kromameter Minolta CR-400 pada tiga titik buah yaitu ujung kanan-kiri dan tengah). Kekerasan diukur menggunakan Sun Rheo meter tipe CR-300 berdasarkan kedalaman tusukan dari jarum penetrometer (kecepatan $0.5 \mathrm{~mm} / \mathrm{s}$ ) per bobot beban tertentu. Total padatan terlarut diukur menggunakan refraktometer Atago 3810 tipe hand-held, dengan prosedur pengukuran sebagai berikut: pembersihan bagian sensor pembaca dengan aquades sebelum pengukuran, dikalibrasi dan selanjutnya sari buah hasil dari penghancuran daging buah diletakkan diatas lensa refraktometer, dan nilai TPT akan terbaca pada lensa. Pengukuran susut bobot diukur menggunakan timbangan digital Mettler tipe PM-4800, kemudian dipersentasekan selisih bobot buah terhadap bobot awal sebelum penyimpanan.

\section{Hasil dan Pembahasan}

\section{Pola Respirasi Buah Duku}

Pengukuran respirasi dilakukan pada kisaran suhu $24^{\circ} \mathrm{C}$ dan $\mathrm{RH} 75 \%$. Hasil penelitian menunjukkan tingkat respirasi buah duku mencapai puncak klimaterik pada jam ke 9 dengan laju respirasi mencapai $65 \mathrm{mg} \mathrm{CO} / \mathrm{kg}$-jam. Buah-buahan dengan laju respirasi melebihi $60 \mathrm{mg} \mathrm{CO} / \mathrm{kg}$-jam tergolong buah berespirasi paling tinggi sehingga kerusakan buah terjadi dengan cepat (Ahmad 2013). Pada Gambar 1. menunjukkan pola laju respirasi buah klimaterik dapat ditandai dengan laju respirasi yang meningkat diikuti dengan peningkatan laju produksi etilen, pada jam yang sama puncak laju produksi etilen berkisar $40 \mathrm{mg} / \mathrm{kg}$-jam. Pola respirasi klimaterik ditandai dengan perubahan laju respirasi yang meningkat mendadak sebelum memasuki proses pematangan. Saat buah-buahan mencapai masak fisiologi, respirasinya mencapai klimaterik yang paling tinggi. Hal ini sejalan dengan Paull (2014) melaporkan bahwa laju respirasi buah duku pada suhu $20^{\circ} \mathrm{C}$ mencapai $50-90 \mathrm{mg} \mathrm{CO} / \mathrm{kg}$ jam. Pola respirasi buah duku utuh maupun buah duku terolah minimal mengikuti pola respirasi buah klimaterik (Adnan 2006)

\section{Pengaruh Ozon Terhadap Jumlah \\ Mikroorganisme Buah Duku}

Pengukuran populasi mikroba buah duku dilakukan dengan cara uji Total Plate Count (TPC). Hasil pengukuran TPC pada Tabel 1. menunjukkan penyimpanan hari ke-3 terjadi penghambatan populasi mikroba pada duku yang mendapat perlakuan ozon dibandingkan perlakuan kontrol. Pada penyimpanan hari ke 6 , perlakuan ozon dengan durasi 60 detik mampu menghambat pertumbuhan migroorganisme hingga 6.11 log cfu/g dibanding kontrol, sedang untuk paparan ozon 20 dan 40 detik masing-masing adalah 6.35 $\log \mathrm{cfu} / \mathrm{g}$ dan $6.32 \mathrm{log} \mathrm{cfu} / \mathrm{g}$. Lamanya paparan ozon mempengaruhi waktu paruh ozon sehingga efektivitas menghambat atau menekan populasi mikroba lebih besar. Lamanya paparan ozon dan lamanya penyimpanan memberi efek yang besar dalam mengurangi pertumbuhan mikroba (Aguayo et al. 2006). Paparan ozon laju $1.38 \times 10^{-4} \mathrm{ppm} /$ detik memberi pengaruh nyata terhadap penurunan populasi mikroba buah duku. Hal ini sejalan dengan Spalding (1996) yang melaporkan konsentrasi

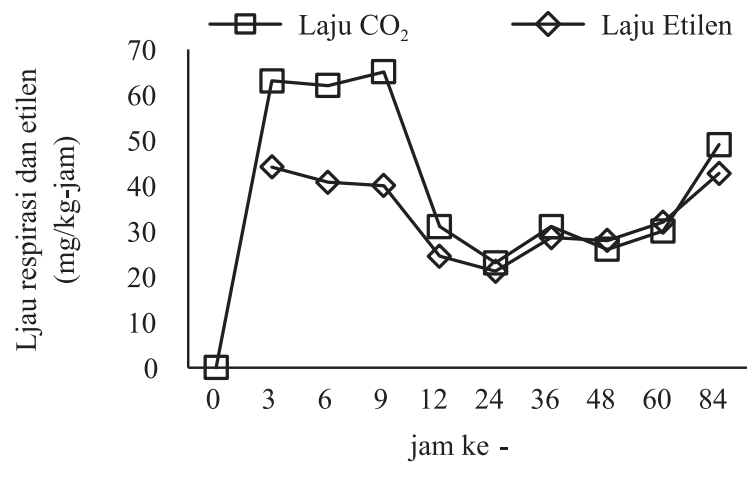

Gambar 1. Laju Respirasi Buah Duku. 
Tabel 1. Total Plate Count Buah Duku.

\begin{tabular}{ccccc}
\hline Perlakuan Pengozonan & \multicolumn{4}{c}{ TPC pada penyimpanan hari ke- (log cfu/g) } \\
\cline { 2 - 5 } & 0 & 3 & 6 & 9 \\
\hline C & $5.98^{\mathrm{c}}$ & $7.24^{\mathrm{a}}$ & $6.42^{\mathrm{a}}$ & $6.19^{\mathrm{a}}$ \\
O20 & $5.40^{\mathrm{a}}$ & $7.12^{\mathrm{b}}$ & $6.35^{\mathrm{a}}$ & $6.36^{\mathrm{b}}$ \\
O40 & $5.10^{\mathrm{b}}$ & $6.56^{\mathrm{c}}$ & $6.32^{\mathrm{a}}$ & $6.01^{\mathrm{c}}$ \\
O60 & $4.63^{\mathrm{d}}$ & $6.12^{\mathrm{d}}$ & $6.11^{\mathrm{b}}$ & $5.63^{\mathrm{d}}$ \\
\hline
\end{tabular}

Huruf yang berbeda pada baris yang sama menunjukkan perbedaan signifikan.

ozon $0.5 \mathrm{ppm}$ dapat menghambat pertumbuhan cendawan Botrytis Cinerea penyebab gejala noda bula warna abu-abu pada buah stroberi dan persik. Glowacz dan Deborah (2016) juga melaporkan kinerja ozon dalam menghambat pertumbuhan mikroba tergantung pada pemberian dosis seperti durasi perlakuan dan penggunaan konsentrasi ozon, serta sensitifitas patogen tertentu terhadap ozon. Hasil uji statistik pada hari ke 0 dan ke 3 penyimpanan menunjukkan adanya perbedaan yang nyata antara kontrol dengan perlakuan paparan ozon 20, 40 dan 60 detik, namun pada hari ke 6 perlakuan kontrol, 20, dan 40 detik tidak berbeda nyata sedang paparan ozon 60 detik berbeda nyata dalam menghambat pertumbuhan mikroba. Lama pemaparan akan meningkatkan efektifitas ozon dalam menekan dan menghambat pertumbuhan mikroba. Namun, pemaparan ozon yang terlalu lama akan mempercepat kerusakan buah. Tekanan oksidasi dari paparan ozon ke buah mempercepat terjadinya reaksi enzimatik yang mengarah pada pencoklatan kulit buah (Miller et al. 2013). Oleh karena itu paparan ozon dengan laju $1.38 \times 10^{-4}$ ppm/detik selama 60 detik merupakan perlakuan ozon yang terbaik karena efektif menghambat pertumbuhan mikroba yang tidak berdampak pada pencoklatan kulit buah.

\section{Perubahan Fisiologi Buah Duku Warna Kulit}

Perubahan warna merupakan indikator penentu kualitas buah selama pematangan dan penyimpanan. Konsumen pada umumnya menyukai warna buah yang mencolok untuk menentukan

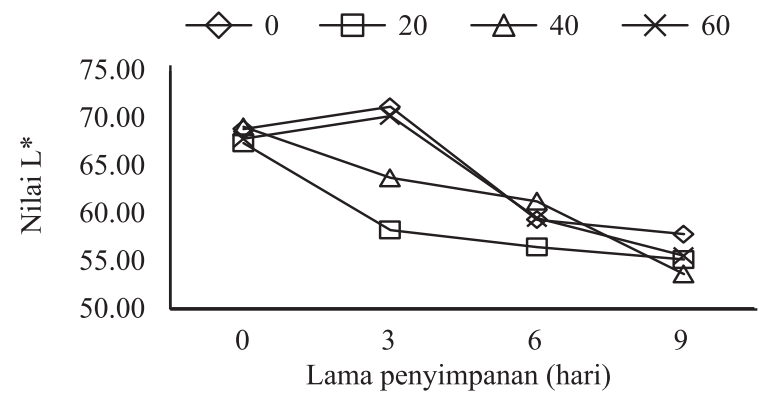

Gambar 2. Pemetaan warna buah Duku selama penyimpanan. kesegarannya. Hasil pengukuran nilai $a^{*}$ dan $b^{*}$ dikonversikan ke dalam satuan kromatik ${ }^{\circ} \mathrm{Hue}(\mathrm{H})$. Pembagian ruang warna hue $\left(\mathrm{H}^{\circ}\right)$ yaitu warna hijau terletak pada $120^{\circ}$ dan warna kuning terletak pada $60^{\circ}$, sehingga semakin rendah nilai derajat $\mathrm{H}$ maka semakin bergeser mendekati warna kuning (Risvita dan Swedia 2017). Hasil penelitian pada Gambar 2. menunjukkan penurunan nilai $\mathrm{H}^{\circ}$ pada penyimpanan hari ke 6 untuk perlakuan kontrol dari 88.03 bergeser ke $77.52^{\circ}$, sedangkan perlakuan ozon 60 detik $\left(89.42^{\circ}\right.$ bergeser ke $80.42^{\circ}$ ), perlakuan ozon 40 detik $\left(89,14^{\circ}\right.$ bergeser ke $\left.83.00^{\circ}\right)$, dan perlakuan ozon 20 detik $\left(88.14^{\circ}\right.$ bergeser ke $\left.80.42^{\circ}\right)$. Uji statistik menunjukkan nilai $\mathrm{H}^{\circ}$ penyimpanan hari ke 6 untuk perlakuan kontrol tidak berbeda nyata dengan perlakuan ozon 60 detik dan ozon lainnya. Hal ini menandakan semakin kecil nilai $\mathrm{H}^{\circ}$ buah duku semakin mengarah ke pencoklatan. hal ini sejalan dengan Venkatachalam dan Meenune (2012) melaporkan bahwa selama pematangan dan penyimpanan terjadi peningkatan aktivitas enzim oksidase dan sintase terutama PPO dan POD yang mengarah pada pencoklatan enzimatik, akibat respirasi yang terus berjalan. Paparan ozon 60 detik yang efektif dalam menghambat mikroba, namun belum optimal mempertahankan nilai $\mathrm{H}^{\circ}$ duku.

\section{Kecerahan Buah Duku}

Hasil pengukuran tingkat kecerahan $\left(L^{*}\right)$ buah duku terjadi perubahan warna kuning cerah menjadi warna coklat gelap seiring dengan lamanya waktu penyimpanan. Nilai $L^{*}$ pada hari ke-3, baik duku dengan perlakuan ozon maupun kontrol mengalami kenaikan yang menunjukkan perubahan warna kuning semakin cerah. Perubahan ini disebabkan oleh degradasi klorofil dan perkembangan senyawa tetraterpenoid kuning pada buah duku selama pematangan dan penyimpanan (Sapii et al. 2000). Penyimpanan hari ke 6 nilai $L^{*}$ terjadi penurunan, masing-masing menjadi 59.42; 56.56; 61.35; dan 59.57 untuk kontrol, perlakuan ozon 20,40, 60 detik. Nilai $L^{*}$ tertinggi ditunjukkan pada perlakuan ozon 40 detik dengan penampakan warna kulit buah duku yang masih kuning dibandingkan perlakuan lainnya. Penurunan nilai $L^{*}$ pada Gambar 3. menandakan penurunan kualitas buah akibat 
proses respirasi yang terus berjalan. Uji statistik menunjukkan paparan ozon 40 detik berbeda nyata pada penyimpanan hari ke 3 . Paparan ozon dapat mempercepat reaksi enzimatik yang menyebabkan terjadinya degradasi warna. Pengaruh paparan ozon akan menghasilkan perubahan yang mengarah pada kehilangan warna dari buah sebagai akibat reaksi oksidatif (Nebel 1975; Sarasa et al. 1993).

\section{Kekerasan}

Perubahan tingkat kekerasan pada Gambar 4. menunjukkan kekerasan buah duku kontrol lebih rendah dibandingkan buah yang mendapat perlakuan ozon. Nilai kekerasan buah duku pada hari ke 6 penyimpanan untuk kontrol adalah 2.47 $\mathrm{N}$ sedangkan untuk perlakuan 20, 40 dan 60 detik nilai kekerasan masing-masing adalah $4.80 \mathrm{~N}$; $4.37 \mathrm{~N}$ dan $4.52 \mathrm{~N}$. Uji statistik menunjukkan nilai kekerasan perlakuan kontrol berbeda nyata dengan perlakuan ozon 20, 40 dan 60 detik. Paparan ozon 20, 40, dan 60 detik mampu menunda pelunakan dibandingkan perlakuan kontrol. Pengaruh paparan ozon diduga mampu membuat daya ikat pada jaringan kulit buah duku semakin merapat dan terjadi pengerutan pada ruang antar sel sehingga kulit buah lebih kuat menahan tekanan. Buah duku selama pematangan meningkatkan aktifitas pektin metilesterase dan polibandropanonase (PMP) yang berpengaruh pada penurunan kekerasan buah, sehingga pengaruh stress oksidasi dari paparan ozon diduga membuat terjadinya penurunan aktifitas PMP ini sehingga kekerasan buah duku dipertahankan (Venkatachalam 2013).

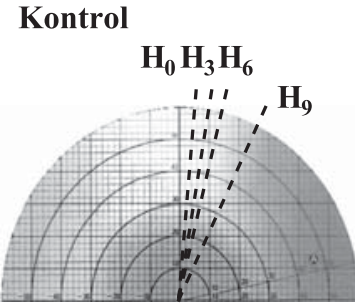

Keterangan :

Hari ke-0: 88,03 (Y)

Hari ke-3: $81.64(\mathrm{Y})$

Hari ke-6: $77.52(\mathrm{Y})$

Hari ke-9: 63.07 (R)

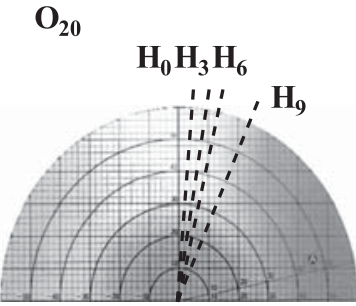

Keterangan :

Hari ke-0: $88.14(\mathrm{Y})$

Hari ke-3: $81.64(\mathrm{Y})$

Hari ke-6: 80.42 (Y)

Hari ke-9: 75.21 (YR)

Hal ini sejalan dengan Skog dan Chu (2001) yang melaporkan bahwa paparan ozon 0.04 ppm pada mentimun selama penyimpanan 17 hari pada suhu $3^{\circ} \mathrm{C}$ efektif mempertahankan kekerasan dan penampilan yang lebih baik dibandingkan perlakuan kontrol. Nadas et al. (2003) juga melaporkan bahwa perlakuan ozon mampu menunda pelunakan buah stroberi yang disimpan pada suhu dingin dan suhu ruang dibandingkan kontrol.

\section{Total padatan terlarut (TPT)}

Pada Gambar 5. menunjukkan nilai TPT buah duku pada hari ke 3 meningkat dengan nilai TPT untuk kontrol dan masing-masing perlakuan adalah $15.9 ; 17.7$; 17.6 ; dan $17.8^{\circ}$ brix. Pada hari ke 6 penyimpanan mulai terjadi penurunan, TPT dengan nilai brix yang masih tetap tinggi adalah buah duku dengan perlakuan paparan ozon selama 60 detik. Hasil uji statistik menunjukkan adanya pengaruh perlakuan ozon terhadap mempertahankan nilai TPT buah duku. Beberapa peneliti melaporkan pengaruh ozon dalam meningkatkan dan mempertahankan nilai TPT selama penyimpanan diantaranya adalah Aguayo et al. (2006) yang melaporkan bahwa TPT buah tomat utuh mengalami peningkatan pada perlakuan ozon $0.5 \mathrm{ppm}$ dibandingkan perlakuan lain selama penyimpanan 15 hari. Kenaikan TPT ini diduga disebabkan oleh tekanan oksidasi dari paparan ozon membuat kenaikan gula lebih cepat. Hal ini sejalan dengan Thwe et al. (2015) yang mengatakan bahwa buah tomat yang dipapar ozon 0.2-0.5 ppm mengalami stress oksidasi menyebabkan rasio gula meningkat dibandingkan

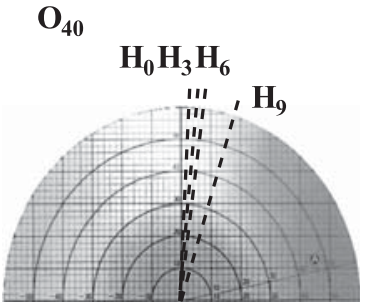

Keterangan :

Hari ke-0: 89.14 (Y)

Hari ke-3: 83.77 (Y)

Hari ke-6: $83.00(\mathrm{Y})$

Hari ke-9: $79.66(\mathrm{Y})$

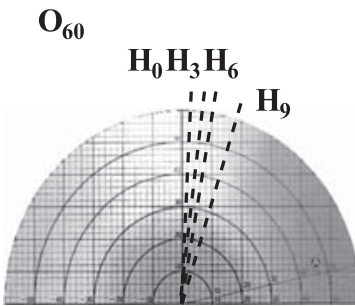

Keterangan :

Hari ke-0: $89.42(\mathrm{Y})$

Hari ke-3: $84.54(\mathrm{Y})$

Hari ke-6: 81.23 (Y)

Hari ke-9: $79.99(Y)$

Gambar 3. Kecerahan Buah Duku.

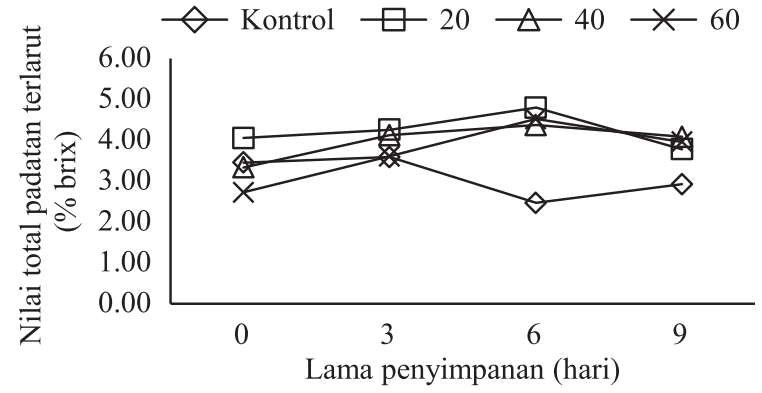

Gambar 4. Nilai Kekerasan Buah Duku.

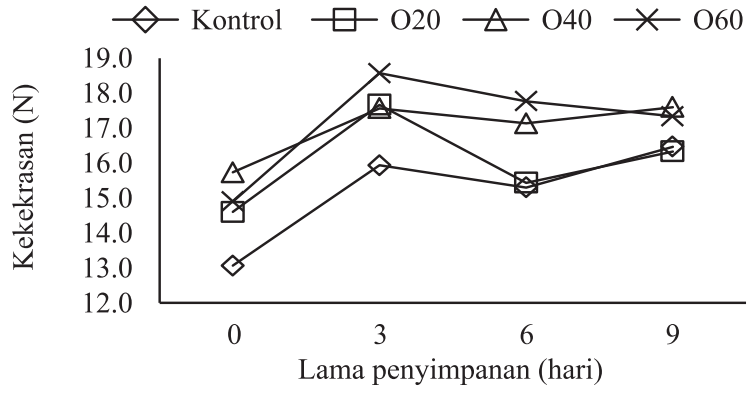

Gambar 5. Total Padatan Terlarut Buah Duku. 
Tabel 2. Data pengamatan jumlah mikroba dan parameter mutu pada hari ke 0 dan hari ke 6 penyimpanan untuk setiap perlakuan.

\begin{tabular}{|c|c|c|c|c|c|c|c|c|}
\hline \multirow{3}{*}{$\begin{array}{l}\text { Parameter Mutu } \\
\text { Buah Duku }\end{array}$} & \multicolumn{8}{|c|}{ Perlakuan Lama Waktu Paparan Ozon } \\
\hline & \multicolumn{2}{|c|}{ Kontrol } & \multicolumn{2}{|c|}{20 detik } & \multicolumn{2}{|c|}{40 detik } & \multicolumn{2}{|c|}{60 detik } \\
\hline & Hari 0 & Hari 6 & Hari 0 & Hari 6 & Hari 0 & Hari 6 & Hari 0 & Hari 6 \\
\hline Uji TPC (log cfu/g) & $5.98^{c}$ & $6.42^{\mathrm{a}}$ & $5.40^{\mathrm{a}}$ & $6.35^{\mathrm{a}}$ & $5.10^{\mathrm{b}}$ & $6.32^{\mathrm{a}}$ & $4.63^{d}$ & $6.11^{\mathrm{b}}$ \\
\hline Nilai $\mathrm{H}^{\mathrm{o}}$ & $88.03^{\mathrm{b}}$ & $77.52^{\mathrm{a}}$ & $88.14^{\mathrm{ab}}$ & $80.42^{\mathrm{a}}$ & $89.14^{\mathrm{ab}}$ & $83.00^{\mathrm{a}}$ & $89.42^{\mathrm{a}}$ & $81.23^{\mathrm{a}}$ \\
\hline Nilai L* & $68.92^{\mathrm{a}}$ & $59.42^{\mathrm{a}}$ & $67.46^{\mathrm{a}}$ & $56.56^{\mathrm{a}}$ & $69.15^{\mathrm{a}}$ & 61.85 & $67.90^{\mathrm{a}}$ & $59.57^{\mathrm{a}}$ \\
\hline Kekerasan $(\mathrm{N})$ & $3.45^{\mathrm{ab}}$ & $2.47^{\mathrm{b}}$ & $4.05^{\mathrm{a}}$ & $4.80^{\mathrm{a}}$ & $3.34^{\mathrm{ab}}$ & $4.37^{\mathrm{a}}$ & $2.73^{b}$ & $4.52^{\mathrm{a}}$ \\
\hline ТРТ (\%Brix) & $13.1^{\mathrm{a}}$ & $15.3^{\mathrm{c}}$ & $14.6^{\mathrm{a}}$ & $15.4^{\mathrm{bc}}$ & $15.7^{\mathrm{a}}$ & $17.1^{\mathrm{ab}}$ & $14.9^{\mathrm{a}}$ & $17.8^{\mathrm{a}}$ \\
\hline Susut Bobot (mg) & $0.00^{\mathrm{a}}$ & $3.92^{\mathrm{a}}$ & $0.00^{\mathrm{a}}$ & $1.73^{\mathrm{ab}}$ & $0.00^{\mathrm{a}}$ & $1.06^{\mathrm{ab}}$ & $0.00^{\mathrm{a}}$ & $0.87^{\mathrm{b}}$ \\
\hline
\end{tabular}

Nilai dalam kotak menunjukkan parameter mutu terbaik.

Huruf yang berbeda pada baris yang sama menunjukkan perbedaan signifikan

kontrol. Aplikasi ozon efektif mempertahankan nilai TPT buah duku, sehingga kemanisan buah duku tetap terjaga.

\section{Susut Bobot}

Penurunan susut bobot yang kecil sangat diharapkan dalam penyimpanan buah duku. Hasil pengukuran pada Gambar 6. menunjukkan penurunan susut bobot pada hari ke 6 penyimpanan susut bobot untuk duku kontrol adalah 3.92\%, sedang untuk masing-masing perlakuan (20, 40 dan 60 detik) adalah $1.73 \%$; $1.06 \%$, dan $0.87 \%$. Penurunan susut bobot terkecil ditunjukkan pada perlakuan ozon 60 detik. Hal ini diperkuat oleh An et al. (2007) yang mengatakan efek dari paparan ozon membuat terjadinya polimerisasi dan epimerisasi pada kandungan selulosa dan hemiselulosa dari dinding sel yang menginduksi penebalan dinding sel sehingga daya ikat pada jaringan kulit buah semakin merapat pada ruang antar sel sehingga transpirasi buah dapat dihambat sebaliknya pada buah duku perlakuan kontrol terjadi pengerutan akibat kehilangan air akibatnya susut bobot tidak dapat dipertahankan. Hal ini sejalan dengan Nadas et al. (2003) yang melaporkan penyimpanan stroberi selama 3 hari pada suhu $2^{\circ} \mathrm{C}$ dengan perlakuan ozon (1.5 ppm) dan kontrol yang dipindahkan ke suhu ruang menunjukkan penurunan susut bobot lebih sedikit dibandingkan dengan kontrol setelah penyimpanan dingin. Achen dan Yousef (2001)

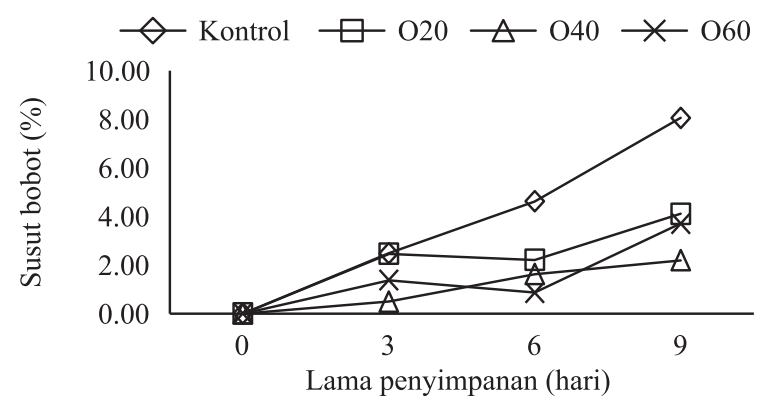

Gambar 6. Susut Bobot Buah Duku. juga melaporkan apel yang diberi perlakuan ozon menghasilkan penurunan bobot dan pembusukan yang lebih rendah dibandingkan kontrol.

\section{Hubungan Pemaparan Ozon terhadap Perubahan Mutu Buah Duku}

Perlakuan ozon yang dikombinasikan dengan suhu dingin $\left(14 \pm 1^{\circ} \mathrm{C}\right)$ hanya dapat mempertahankan mutu buah selama 6 hari penyimpanan. Namun hasil ini lebih baik dibanding dengan kontrol berdasarkan jumlah mikroba dan parameter mutu yang meliputi warna kulit, kekerasan, TPT dan susut bobot. Hasil penelitian menunjukkan perlakuan ozon yang memberi efek terbaik adalah paparan ozon 60 detik dengan laju $1.38 \times 10^{-4} \mathrm{ppm} /$ detik. Pada Tabel 5. menunjukkan perlakuan ozon 60 detik efektif menekan mikroba hingga 6.11 log cfu/g dengan parameter mutu terbaik seperti nilai kekerasan sebesar $4.80 \mathrm{~N}$, dengan nilai TPT bertahan hingga $17.8^{\circ} \mathrm{brix}$ dan penurunan susut bobot hanya sebesar $0.87 \%$, sedangkan paparan ozon 40 detik memperoleh parameter mutu terbaik dengan perubahan warna kulit $\left(\mathrm{H}^{\circ}\right) 83.00^{\circ}$. Dengan demikian paparan ozon 60 detik tidak memberikan pengaruh besar terhadap perubahan warna buah duku, tetapi secara signifikan menekan pertumbuhan mikroba, mempertahankan kekerasan dan meningkatkan total padatan terlarut serta menekan kenaikan susut bobot selama penyimpanan. Parameter warna seperti perubahan warna kulit $\left(\mathrm{H}^{\circ}\right)$ menunjukkan paparan ozon 40 detik menghasilkan nilai yang terbaik namun tidak berbeda nyata dengan perlakuan 60 detik. Hal yang sama untuk parameter kekerasan, diperoleh perlakuan ozon 20 detik menghasilkan nilai kekerasan terbaik diikuti oleh perlakuan ozon 60 detik, namun nilai kedua perlakuan tidak berbeda nyata. Hubungan perubahan nilai TPC, Warna, kekerasan, TPT dan susut bobot buah duku masingmasing menunjukkan adanya respon antara waktu paparan ozon terhadap perubahan mutu buah selama penyimpanan. 


\section{Simpulan}

Pola repirasi buah duku termasuk buah klimakterik dengan laju respirasi tinggi mencapai $65 \mathrm{mg} \mathrm{CO} / \mathrm{kg}$-jam dan laju produksi etilen berkisar $40 \mathrm{mg} / \mathrm{kg}$-jam. Lamanya waktu papar ozon masingmasing memberi respon yang berpengaruh pada tingkat efektifitas ozon menekan pertumbuhan mikroba dan perubahan mutu seperti kekerasan, warna, TPT dan susut bobot buah duku. Ozon dengan laju $1.38 \times 10^{-4} \mathrm{ppm} /$ detik yang dipaparkan selama 60 detik mampu menekan pertumbuhan mikroorganisme pada penyimpanan hari ke 6 yaitu $6.11 \mathrm{log}$ cfu/g lebih kecil dibanding dengan kontrol sebesar 6.42 log cfu/g, dan tetap menghasilkan perubahan mutu yang lebih baik dari perlakuan ozon yang lainnya, terutama pada tingkat kemanisan buah duku (17.8 ${ }^{\circ}$ brix) dan susut bobot terendah $0.87 \%$. Walau warna dan kekerasan yang terbaik dihasilkan oleh perlakuan paparan ozon 40 detik dan 20 detik namun nilainya tidak berbeda nyata secara statistik dengan perlakuan 60 detik.

\section{Saran}

Perlakuan ozon yang dikombinasikan dengan suhu dingin $\left(14 \pm 1^{\circ} \mathrm{C}\right)$ masih belum mampu memperpanjang masa simpan yang diharapkan yaitu 15 hari untuk waktu transportasi dan waktu display penjualan sehingga perlu kajian lebih lanjut untuk perlakuan kombinasi antara laju dan waktu papar ozon yang tepat agar kinerja ozon lebih optimal dan dikombinasikan dengan perlakuan lain seperti kemasan, penambahan bahan anti browning seperti asam oksalat. Hasil penelitian menunjukkan adanya perubahan mutu terutama warna yang cepat terjadi saat buah dikeluarkan dari ruang simpan bersuhu rendah, sehingga perlu dikaji untuk dapat diperlambat agar dapat memperpanjang masa jual.

\section{Daftar Pustaka}

Achen, M. and A.E. Yousef. 2001. Efficacy of ozone against Escherichia coli 0157:H7 on apples. J. Food Sci. Vol. 66(9): 1380-4.

Adnan. 2006. Penyimpanan buah duku terolah minimal dalam kemasan atmosfer termodifikasi [tesis]. Bogor (ID): Institut Pertanian Bogor.

Aguayo, E., V.H. Escalona, F. Artes. 2006. Effect of cyclic exposure to ozone gas on physicochemical, sensorial and microbial quality of whole and sliced tomatoes. J Postharvest Biology and Technology. Vol. 39(2): 169-177.

Ahmad, U. 2013. Teknologi Penanganan Pascapanen Buah dan Sayuran. Yogyakarta: Graha IImu.

An, J., M. Zhang, Q. Lu. 2007. Changes in some quality indexes in freshcut green asparagus pretreated with aqueous ozone and subsequent modified atmosphere packaging. Journal of Food Engineering. Vol. 78(1): 340-410.

Asgar, A. 2014. Teknologi ozonisasi untuk mencuci sayuran. J. Iptek Hort. Vol. 1(10): 10-13.

[DTI] Danish Technology Institute. 2008. Guide Packaging Fresh Fruit and Vegetables. Innovation Act. Denmark. p 7-8.

Forney, C.F., J. Song, P.D. Hildebrand, L. Fan, and K.B. McRae. 2007. Interactive effects of ozone and 1-methylcyclopropene on decay resistance and quality of stored carrots. Postharvest Biology and Technology. J Sci. Food Agric. Vol. 45(3): 341-348.

Hairunnisa, Nunung. 2014. Penyebab dan Pencegahan Browning pada Langsat (Lansium domesticum). Pontianak: Dinas Pertanian, Perikanan dan Kehutanan.

Glowacz, M. and R. Deborah. 2016. The practicality of using ozone with fruit and vegetables. J. Sci Food Agric. Vol. 96(14): 4637-4643.

Lichanporn, I., V. Srilaong, C. Wongs-Aree, S. Kanlayaranat. 2008. Effect of strorage temperature on peel colour and physiological changes of longkong fruit (Aglaia dookkoo Griff). J. Acta Hort. Vol. 804: 599-604.

Miller, F.A., C.L. Silva, T.R. Brandao. 2013. A review on ozone-based treatments for fruit and vegetables preservation. Journal Food Engineering Reviews. Vol. 5(2): 77-106.

Nadas, A., M. Olmo, J.M. Garcia. 2003. Growth of Botrytis Cinerea and strawberry quality in ozoneenriched atmospheres. Journal of Food Science. Vol. 68(5): 1798-1802.

Nebel, C. 1975. Ozone decolorization of secondary dye laden effluents. Second Symposium on Ozone Technology, Montreal, May 11-14 ( $p$ 336-358).

O'Donnell, Colm, B.K., Tiwari, P.J. Cullen and G.R. Rip. 2012. Status and Trend of Ozone in Food Processing. Wiley-Blackwell a John Wiley \& Sons, publishing Ltd: UK.

Paull, R.E. 2014. Review. Longkong, Duku, and Langsat: Postharvest Quality-maintenance Guidelines. College of Tropikal Agriculture and Human Resources. University Hawaii.

Risvita, M. dan E.R. Swedia. 2017. Aplikasi pengolahan citra untuk menentukan tingkat kematangan buah pisang dengan menggunakan ruang warna hue. J.Teknol.Rekayasa. Vol.22(1):43-47

Sarasa, J., M.P. Rache, A. Puig, M.P. Ormed, P. Mutuberria, and J.L. Ovellerio. 1993. Proceedings of the $11^{\text {st }}$ Seminar: ozone world congress, San Francisco, [tanggal tidak diketahui]. p 91-105.

Sirichote, A.S., C. Chanawirawan, B. Puengphian, S. Jongpanyalert, A. Pisuchpen, Rugkong. 2015. Storage Quality of Longkong (Lansium domesticum Corr.) Fruit as Affected by Ozonated Water and Sodium Hypochlorite Pretreatment. 
Journal Acta Horticulturae. Vol. 1088(1088): 201-206.

Sujatha, W. dan W.W. Ni. 2017. Buku Ajar Fisiologi dan tehnologi Pascapanen (Buah dan Sayuran). Bulit Jimbaran: Udayana Univesity Press.

Skog, L.J. and C.L. Chu. 2001. Effect of ozone on qualities of fruits and vegetables in cold storage. Can. J. Plant Sci. Vol. 81(4): 773-778.

Spalding, D.H. 1968. Effects of Ozone Atmospheres on Spoilage of Fruits and Vegetables after Harvest. Marketing Research Report. Department of Agriculture: Washington, D.C.

Thaer, Y., A. Ricella, M.D. Anna. 2015. Ozone for post harvest treatment of Apple fruits. J Pytopathologia mediterranea. Vol. 54(1): 94103.
Tilaar, M., W.L. Wih, A.S. Ranti, S.M. Wasitaatmadja, Suryaningsih, F.D. Junardy, Maily. 2007. Review of Lansium domesticum Correa and its use in cosmetics. J. Bol Latinoamericano y del Caribe de Plantas Medicinales y Aromaticas. Vol. 7(4): 183-189.

Thwe, A.A., V. Gilles, G. Helene, G. Frederic, P. Jessada, K. Poonpipope. 2014. Effects of acute ozone stress on reproductive traits of tomato, fruit yield and fruit composition. J Sci Food Agric. Vol. 95: 614-620.

Venkatachalam, K. 2013. Changes in quality and enzymes of Longkong (Aglaia dookkoo Gri $\square$.) fruit during storages as affected by maturation, package and methyl jasmonate treatment. (Tesis). Prince of Songkla University, HadYai. 